\title{
Local Depressions in Country Rock of Kimbelites as a New Exploraion Critter (by the Example of Zolotitsa Field, Arkhangelsk, Russia)
}

\author{
Erinchek, Yu.M. ${ }^{1}$, Milshtein, E.D. ${ }^{1}$, Saltykov, O.G. ${ }^{1}$, and Verzhak, V.V. ${ }^{2}$
}

1. Geological Research Institute (VSEGEI), St. Petersburg 199106,Russia

2. Severgeolkom, Arkhangelsk 163045, Russia

The knowledge of kimberlite intruding mechanism and its influence upon country rocks is the main problem of kimberlite-geology. The traces of this influence should be displayed most contrast in the upper parts of diatremes. However, as a rule, just these very parts of diatremes are eroded. By this reason a lot of attempts to reveal kimberlite influences upon country rocks were unsuccessful. The investigation of kimberlite country rocks structure in the area with low eroded kimberlite pipes is given below.

Kimberlite pipes of Zolotitsa field intrude weakly lithified Vendian arenaceous sediments and are overlapped by carbonaceous-terrigenous Middle Carboniferous and by Quaternary (Arkhangelsk Kimberlite Province, 1995). The upper part (150-200 m) of Vendian rocks, called padunskaya formation, is represented by sandstones, argillite-sandstones (Stankovskiy et. al., 1985). It is tested by network of different depth holes.

The special technique that had been worked up and approved for study of carbonaceousterrigenous country rock of kimberlites in Yakutian province (Saltykov et. al., 1991) was used for the close structural mapping of Vendian upper parts (padunskaya formation) in Zolotitsa field. The technique allows to identify and to map the low contrast marking horizons on the basis of the drilling and logging data. All types of borehols including shot ones are used. The set of close structural maps for several horizons of padunskaya formation was created.

The study of Vendian structure has shown the following. On a background of general south-east monoclinal folding of Vendian horizons low contrast negative local structures framing pipes are noticed (Erinchek et. al., 1997). We called them us subsidence depression. Subsidence depressions are revealed for all known pipes of Zolotitsa field. They are recorded in near-pipe space by flexurelike or arc-like breaks of country rock horizons. In geological section this local depressions are expressed by appreciable submersion of Vendian horizons in the direction to the pipe body. Near pipe depressions are marked at all levels of Vendian upper parts. Depressions measuring from 1,01,5 to $3,0-2.5 \mathrm{~km}$ are oval or subisometric in plan. It is in 6-8 times more than pipe sizes on the level of Vendian erosive surface. The depression amplitude varies from 10-15 m to 40-50 m. and, as a rule, appreciably accrues upwards to the section. The pipes allocate in the central or marginal parts of subsidence depressions. Sometimes depressions frame a few converged pipes. On the close geological map of padunskaya formation erosion roof (with the removed cover of overlapping sediments) the depressions are corresponded to local areas (spots) of the youngest horizons of country rocks. At the adjoining areas this horizons are absent.

The fragment of the structural map of Zolotitsa field central part is enclosed in the figure. The subsidence depressions are marked for pipes Snegurochka, Arkhangelskaya, Pionerskaya. Two converged pipes Karpinsky-1 and Karpinsky- 2 are framed by the same depression. The united of depressions are traced as the linearly extended chain, fixing north-northeast kimberlite-host zone.

Probably, subsidence depressions have arisen as a consequence of kimberlite intruding. However, mechanism of their formation remains debatable. Several variants of their genesis may be assumed. At one hand, subsidence depressions could be formed as the result of partial vacation of magma center by kimberlite pipe intruding. In this case depressions would be manifested most precisely on significant depths, and their contrast would be smoothed out upwards the section. But vice versa, all known depressions are precisely marked in the levels of upper parts of the pipes. 


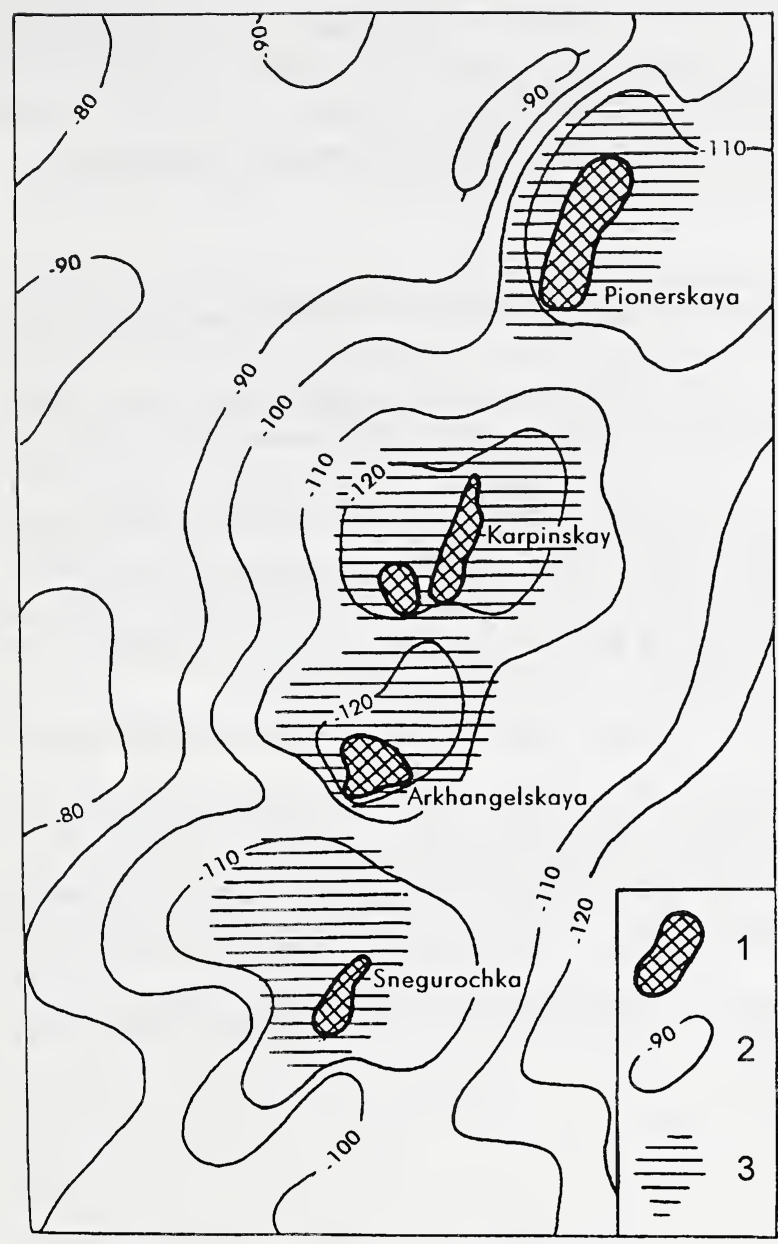

Figure. Fragment of structural map of kimberlite country rocks in Zolotitsa field 1 - Kimberlite pipes, 2 - structure contours of Vendian padunskaya formation sole, 3 sole of local subsidence depressions

An other reason of the formation of the subsidence depressions could be the influence of explosive processes to the country rocks during pipe intruding. In this case the stresses which were realized in forming of pipe explosion crater at the same time formed peripheral faults and jointing of country rocks. Subsidence of jointy country rocks around the pipes could be caused by dumping of separate blocks along parabolic-concentric (peripheral) faults. (Nikitin, 1980). Using this mechanism we can expect the forming of depressions on the level of the crater part.

Also depressions could be formed as the result of the breach of hydrodynamic regime of underground waters in horizontal - layered country rocks in a course of foreign body appearance. Chemical subtraction of ready-soluble components lead to loosing of volume in country rock horizons surround the pipes.

By our opinion, two main processes are responsible for the forming of subsidence depressions: the pipe explosion and subsequent chemical subtraction. So, the forming of the depressions had begun at the time of kimberlite intruding and has been developing up to resent time. During intruding the country rocks surround the pipe were destroyed and partly dumped into the pipe. Then the subsidence of country rock horizons (with some reduction of their volume) has being occurred surround the pipes. Exactly these processes allow us to explain the peculiarities of subsidence depressions fixed around the pipes of Zolotitsa field. The depressions are marked on the level of pipe crater and are tracked down to nearly $200 \mathrm{~m}$, their contrast is growing upwards the section. Postkimberlite sediments, including Quaternary above the depressions are thicker than at the adjoining areas. The negative forms of surface occupied by lakes and bogs are often connected with the depressions.

Subsidence depressions, similar by their morphology to Zolotitsa field ones, are revealed in vicinities of many kimberlite pipes of Alakit field of Yakutian diamond-bearing province. (Kruchkov et.al., 1990; Kruchkov et.al., 1991; Nikitin, 1980). As well, subsidence depressions around the explosion pipes are known in the other regions. They are brightly pronounced in surrounding of mafic pipes of Angar iron-ore province of Southern Siberia (Nikulin et.al.,1991). The size of the depressions around mafic pipes and groups of bodies reaches $7 \mathrm{~km}$ in a diameter (pipes themselves are up to $1,5 \mathrm{~km}$ ), having the amplitude up to $350 \mathrm{~m}$. So, huge amplitude can be explained by the fact that pipes intrude salt-bearing horizons on the depth.

Thus, the result of research is revealing of precise traces of influence of kimberlite intruding to the structure of country rocks. All investigated pipes of Zolotitsa kimberlite field are accompanied 
by subsidence depressions of country rocks, which are significant lager than pipes. It is possible to assume, that the forming of similar local low-amplitude negative structures accompany with intruding of the main parts of explosion subvertical bodies. These subsidence depressions may be used as an important exploration structural criteria in the areas with small eroded kimberlites.

\section{References}

Arkhangelsk Kimberlite Province, 1995, Sixth International Kimberlite Conference. Field Guide Book, Novosibirsk, $31 \mathrm{p}$.

Erinchek, Yu.M., Rykhlova, T.I., Saltykov, O.G., Milshtein, E.D., and Kaplan, A.D., 1997, Reflection of kimberlite pipes in the structure of country rocks of Zolotitsa field: Okhrana i Razvedka nedr, 5, p. 9-12.

Kruchkov, A.I., Nikulin, V.I., Krasinets, S.S., Lelukh, M.I., Ustinov, V.N., and Fon-de-Flaas, G.S., 1990, New type kimberlite diatremes in Daldyn-Alakit area: Sovetskaya Geologiya, 10, p. 32-37.

Kruchkov, A.I., Nikulin, V.I., Krasinets, S.S., Lelukh, M.I., Lubimenko, V.F., Somov, S.V., and Fon-de-Flaas, G.S., 1991, Conditions of localization and peculiarities of a new kimberlite body structure in Aikhal region (Siberian platform): Geoogiya i Geofizika, 5, p. 61-69.

Nikitin, B.M.,1980, Deformations of country rocks by kimberlite pipes forming: Izvestiya AN USSR, Seriya Geologicheskaya, 11, p. 41-49.

Nikulin, V.I., Fon-de-Flaas, G.S., and Baryshev, A.C., 1991, Explosive-volcanic basaltic oreforming system (Angar iron-ore province): Geologia Rudnykh Mestorogdeniy, 3, p. 26-40.

Saltykov, O.G., Erinchek, Yu.M., Ustinov, V.N., and Milshtein, E.D., 1991, The Late Paleozoic terrigenous collectors of diamond in the eastern flank of the Tunguss syneclise. St-Petersburg, $223 \mathrm{p}$.

Stankovskiy, A.F., Verichev, E.M., and Dobeiko, I.P., 1985, Vendian of south-eastern Belomoriya: Vendian system, v. 2. Moscow, Nauka, p.67-75 